\title{
MALGORZATA PACHOWICZ
}

Państwowa Wyższa Szkoła Zawodowa w Tarnowie, Instytut Humanistyczny, Zakład Filologii Polskiej

\section{Słowo w komentarzach internautów Uwagi o (nie)oficjalnym dyskursie medialnym}

Internetowa komunikacja interaktywna ${ }^{1} \mathrm{z}$ przemiennością ról nadawcy i odbiorcy daje możliwość wypowiadania się każdemu, kto jest zainteresowany zamieszczoną w Sieci informacją, wiadomością, komunikatem, tematem. W przestrzeni Internetu osoby chętne do rozmowy i mające takie same zainteresowania mogą być np. uczestnikami różnotematycznych grup dyskusyjnych, czyli forów dyskusyjnych. Mogą także wyrażać swoje opinie i komentować podawane w portalach internetowych wiadomości bezpośrednio pod zamieszczoną na stronie informacją, w miejscach opatrzonych nagłówkami typu ,komentarze” (Onet.pl) lub „wasze komentarze” (Interia.pl). Swoistym zaproszeniem do włączenia się w tok dyskusji np. w portalu Interia.pl są bezpośrednie zwroty do adresata ,skomentuj artykuł”, „dodaj komentarz”, a w portalu Onet.pl - „napisz komentarz”.

Internauci wyrażają swoje poglądy, posługując się słowem w różnych jego znaczeniach i kombinacjach modyfikujących znaczenia innych słów. „W Sieci nie widać twarzy rozmówcy. Widoczne są tylko słowa i to one determinują stosunki, kontakty. Ludzie posługują się słowami w bardzo różny sposób i szybko dostosowują styl wypowiedzi do określonego kontekstu społecznego, narzuconego przez współrozmówców" [Golus 2004: 34]. W wirtualnej dyskusji na forum słowo widoczne na ekranie komputera jest nośnikiem informacji, w nim także odzwierciedlają się emocje internautów i ich interpretacja rzeczywistości.

Te wybrane ${ }^{2}$ właściwości słowa jako tworzywa wypowiedzi internautów, a także analiza komentarzy w kontekście dyskursu medialnego są przedmiotem

${ }^{1}$ J. Grzenia określa Internet jako medium interaktywne, a interaktywność uznaje za cechę „niejako immanentną” Internetu [Grzenia 2007: 18-27].

2 Słowa „służą do nazywania elementów rzeczywistości, ich cech i relacji, jakie między nimi zachodzą, do nazywania stanów wewnętrznych, psychicznych człowieka, a także do wyrażania uczuć, emocji i innych stanów ekspresywnych. [...] Pewna grupa wyrazów nie odnosi się do rzeczywistości językowej, lecz służy do wiązania innych wyrazów w jednostki tekstu [...]" [Jadacka, Markowski, Zdunkiewicz-Jedynak 2008: 129]. 
przedstawianych rozważań. Podstawę materiałową stanowią wypowiedzi internautów, czyli ich komentarze odnoszące się do wiadomości zatytułowanej Silne trzęsienie ziemi. Sa zabici i ranni ${ }^{3}$ zamieszczonej w dniu 24 kwietnia 2013 r. na stronie głównej portalu Interia.pl w dziale „Fakty”.

Tak sformułowany tytuł wiadomości informował o wydarzeniu (trzęsieniu ziemi), jego randze (silne) oraz poszkodowanych osobach (zabitych $i$ rannych). Była to informacja ogólnikowa, ale skonstruowana w taki sposób, aby wzbudzić zainteresowanie internauty i zachęcić go do zapoznania się ze szczegółami tego zdarzenia, które pojawiały się po kliknięciu w nagłówek ${ }^{4}$. W ten sposób czytelnik uzyskiwał dostęp do pełnego tekstu wiadomości, w którym zostały podane dokładne informacje dotyczącego tego, co się wydarzyło:

Siedem osób zginęlo w trzęsieniu ziemi, dziesiątki rannych ${ }^{5}$. Co najmniej siedem osób zginęło, a 75 zostało rannych w trzęsieniu ziemi o sile 5,7, do którego doszło w środę w południowo-wschodnim Afganistanie - powiadomiły władze lokalne. Jest to pierwszy bilans ofiar tego trzęsienia, przekazany przez agencję AFP. Z kolei Reuters, powołując się na władze prowincji Kunar, podaje niższą liczbę ofiar - cztery osoby zabite i prawie 70 rannych, zaznaczając, że bilans ten, jak obawiają się władze, może wzrosnąć. W prowincji Kunar zawaliły się setki domów. Wiele z nich, zbudowanych z tradycyjnej cegły suszonej na słońcu, już wcześniej naruszyły ulewne deszcze. Epicentrum wstrząsów znajdowało się $25 \mathrm{~km}$ od Dżalalabadu we wschodnim Afganistanie w pobliżu granicy pakistańskiej. Odczuwalne były również w New Delhi, gdzie zakołysały się budynki, a także w regionie Kaszmiru na granicy pakistańsko-indyjskiej i w stolicy Pakistanu - Islamabadzie"6.

Pełny tekst wiadomości zawierał więc informacje o liczbie zabitych i rannych (z zastrzeżeniem, że te dane mogą ulec zmianie), sile wstrząsu, jego epicentrum i miejscu zdarzenia, a także o skutkach kataklizmu. Pod tą informacją internauci mogli zamieszczać swoje komentarze ${ }^{7}$, a przejście na forum ${ }^{8}$ umożliwiało śledzenie pojawiających się wypowiedzi osób, które komentowały podaną wiadomość.

${ }^{3}$ http://www.interia.pl/ [dostęp 24.04.2013].

${ }^{4}$ Nagłówek na stronie głównej portalu zapowiada pełny tekst wiadomości, informuje o konkretnym wydarzeniu i zachęca do lektury całego tekstu [Żydek-Bednarczuk 2004a: 17; Pachowicz 2011: 324-325]. Wystarczy więc kliknąć w wybrany aktywny tytuł wiadomości, aby przenieść się na stronę zawierającą szczegółowy tekst zapowiedziany na stronie głównej portalu.

${ }^{5}$ Jest to tytuł poszerzonej wersji wiadomości, do której odsyłał nagłówek ze strony głównej portalu Interia.pl

${ }^{6} \mathrm{http}: / /$ fakty.interia.pl/swiat/news-siedem-osob-zginelo-w-trzesieniu-ziemi-dziesiatki-rannych,nId,959560\#commentsZone List [dostęp 24.04.2013].

7 Do dyskusji na temat przedstawionego wydarzenia zachęcał internautów zwrot: „Skomentuj artykuł: Siedem osób zginęło w trzęsieniu ziemi, dziesiątki rannych” oraz konkretne polecenie: „Przejdź do forum”, na którym można zamieszczać komentarze, http://fakty.interia.pl/swiat/ news-siedem-osob-zginelo-w-trzesieniu-ziemi-dziesiatki-rannych,nId,959560\#commentsZone List [dostęp 24.04.2013].

${ }^{8} \mathrm{http}$ ://forum.interia.pl/siedem-osob-zginelo-w-trzesieniu-ziemi-dziesiatki-rannych-komentarze,catId,1895,dId,2195066 [dostęp 24.04.2013]. 


\section{Słowo jako reakcja na zaistniałe wydarzenie}

Wypowiedzi internautów zamieszczane na forum odnoszą się do podanej wiadomości o tragicznym w skutkach trzęsieniu ziemi w Afganistanie. Oczekiwać by można, że zgodnie z zasadami komunikacji językowej internauci zinterpretują otrzymaną informację zgodnie z intencją nadawcy ${ }^{9}$. Skoro nadawca informuje o zniszczeniach i śmierci wielu osób, to reakcją odbiorcy powinny być słowa współczucia i chęci niesienia pomocy poszkodowanym. Taka postawa odzwierciedla się jednak zaledwie w jednej wypowiedzi: „Wieczny odpoczynek dla Ofiar i wyrazy współczucia dla rodzin" ${ }^{10}$.

Wypowiedź ta jest kontaminacją modlitwy za zmarłych i kondolencji. Tradycyjna formuła modlitwy-prośby (,Wieczny odpoczynek racz im dać, Panie, a światłość wiekuista niechaj im świeci. Niech odpoczywają w pokoju. Amen") została w tym wpisie zmodyfikowana, zredukowana do dwóch słów „wieczny odpoczynek” i pozbawiona aklamacji ,amen”. Nadawca dokonał także transformacji i wyraźnie wskazał, dla kogo prosi o pokój wieczny (,dla Ofiar”), wyrażając przy tym, poprzez zapis dużą literą, szacunek dla zmarłych. Drugą część wypowiedzi internauty można określić jako kondolencje, które odbiegają jednak od kanonicznego wzorca:

wiem że stało się coś co jest dla ciebie złe (ktoś w twojej rodzinie umarł) ${ }^{11}$
sądzę że czujesz smutek z tego powodu
mówię: i ja czuję smutek z tego powodu
mówię to bo chcę żebyś się czuł mniej smutny. [Wierzbicka 1983: 130]

Kondolencje zostały ograniczone do stereotypowego bezpośredniego wyrażenia performatywnego „wyrazy współczucia”, mającego ogólną treść „mówię, że smucę się razem z tobą z powodu zdarzenia X" [Marcjanik 1997]. W tej części wypowiedzi internauta również wskazał adresata, kierując wyrazy współczucia „dla rodzin” (poszkodowanych w trzęsieniu ziemi), nie zapisał jednak dużą literą odbiorcy, do którego skierował te słowa. Przytoczona wypowiedź jest przykładem aktu współczucia, w którym słowa są reakcją na przedstawione tragiczne zdarzenie.

Inny z internautów swój komentarz do zaistniałej sytuacji ograniczył do jednego słowa refleksji „życie”. Nawiązał więc m.in. do wyrażeń „takie jest życie”

${ }^{9}$ W tym przypadku wiadomość została przekazana przez Polską Agencję Prasową; tekst wiadomości jest sygnowany skrótem PAP.

${ }^{10}$ Wszystkie analizowane przykłady pochodzą ze strony: http://fakty.interia.pl/swiat/news-siedem-osob-zginelo-w-trzesieniu-ziemi-dziesiatki-rannych,nId,959560\#commentsZone List [dostęp 24.04.2013]. Przytaczając wypowiedzi, zachowuję oryginalną pisownię internautów.

${ }^{11}$ M. Marcjanik uważa, że w zaproponowanej przez A. Wierzbicką eksplikacji semantycznej kondolencji należałoby dokonać uzupełnienia, ponieważ bliskim zmarłym może być także osoba spoza kręgu rodziny [Marcjanik 1997: 77]. 
lub „samo życie” odnoszących się do ludzkiego losu, którego kresem jest śmierć. W kontekście przytoczonego zdarzenia ten niezwykle lakoniczny komentarz z ukrytą wieloznaczną intencją nadawcy skłania pozostałych uczestników forum do zadumy i zastanowienia się zarówno nad życiem, jak i śmiercią, która może przyjść niespodziewanie. Taki sposób komentowania może być również odzwierciedleniem postawy nadawcy i jego emocji lub ich braku. Konstatacja „życie” to $\mathrm{z}$ jednej strony odzwierciedlenie niewzruszonej postawy nawet $\mathrm{w}$ obliczu nieszczęścia, z drugiej jednak wyrażenie uczuć osoby, która łączy się w bólu z tymi, którzy przeżyli kataklizm i stracili swoich bliskich ${ }^{12}$.

Ukrytą intencję ma także komentarz „,coraz częściej te trzęsienia, to już chyba 7 takie dosyć silne w przeciągu 3 tygodni”. Jest to wypowiedź, w której nadawca zwraca uwagę jedynie na częstotliwość występowania kataklizmu i jego siłę, zapominając niejako, że w wyniku tego trzęsienia ziemi zginęli ludzie. Jeśli jednak przeczyta się ten komentarz kolejny raz, można dostrzec, że słowa nadawcy wyrażają niepokój i lęk. Internauta zwraca uwagę na stopniowe i stałe nasilanie się tego typu kataklizmów, używając połączenia przysłówków „coraz częściej”; podaje także dane dotyczące liczby takich zjawisk i czasu ich występowania (,to już chyba 7 [...] w przeciągu 3 tygodni”). Jego niepokój budzi także siła trzęsienia ziemi. Zatem wpis na forum będący reakcją na informację podaną przez PAP, pomimo pozorów wypowiedzi neutralnej, ma charakter emocjonalny i jest swoistym aktem współczucia skierowanym do poszkodowanych.

$\mathrm{O}$ ile przytoczone powyżej komentarze internautów to reakcje na tragiczne w skutkach wydarzenie i w sposób bezpośredni lub pośredni zawierają słowa współczucia skierowane do poszkodowanych, to dla pozostałych osób zabierających głos na forum ta informacja stała się jedynie punktem wyjścia do sformułowania wypowiedzi, w których deprecjonuje się osoby publiczne bądź odwołuje się do wydarzeń z życia politycznego czy społecznego. Zamieszczenie na forum tego typu komentarzy jako reakcji na wiadomość o nagłej i tragicznej śmierci wielu ludzi może więc świadczyć o zmianie zachowań w sytuacji trudnej, która wymaga aktów wsparcia, dodawania otuchy, podtrzymywania na duchu czy nawet udzielania rad.

Przykładem takiej deprecjonującej reakcji jest ironiczny i złośliwy wpis „Grycanki wdepły na salony”. Intencja nadawcy jest czytelna dla internautów śledzących życie celebrytów, a do nich zaliczają się Marta Grycan i jej córki ${ }^{13}$, ponieważ

12 Odczytanie intencji internauty jest utrudnione, ponieważ nie posługuje się on żadnymi graficznymi znakami typowymi dla komunikowania się w Internecie, w których uzewnętrzniają się emocje nadawcy (brak w tej wypowiedzi np. emotikonów czy zapisu dużymi literami).

13 „Marta Grycan od pewnego czasu pojawiała się na warszawskich salonach, a to na gali Doskonałość Roku, a to na imprezie Oskary Fashion. Teraz dołączyły do niej dwie córki: Weronika i Wiktoria. Trzy panie niedawno pojawiły się na premierze nowego teledysku Dody. Czy będą nowymi celebrytkami?", http://zyciegwiazd.onet.pl/302409,0,marta-grycan-z-corkami-wiktoria-i-weronika-czy-to-fotonews_detail.html [15.06.2013]. 
w kolejnej wypowiedzi znalazło się stwierdzenie „Współczucia dla tego, komu je podsunięto...”. Podobną intencję zawiera także inny wpis: „gesslerowa się wyrąbała [...]", w którym pojawia się nazwisko innej celebrytki Magdy Gessler ${ }^{14}$. Eksplikacja semantyczna tych głosów w dyskusji jest negatywna i można ją ująć następująco: „wiem, że zjawisko X wywołało pojawienie się Y w miejscu Z”. Dodatkowo, negatywny wydźwięk tych wypowiedzi zostaje wzmocniony przez ujemnie nacechowane czasowniki: „wdepły” i „wyrąbała”"15 użyte w potocznych znaczeniach, które podkreślają niechęć do celebrytek.

Kolejne wypowiedzi, których punktem wyjścia stała się wiadomość przekazana przez PAP, zawierają odwołania do postaci z polskiej sceny politycznej. Pojawia się więc wpis-pytanie retoryczne odnoszące się do premiera polskiego rządu ,a kiedy zatrzęsie tuskiem” oraz wpis-aluzja do Sławomira Nowaka, ministra w rządzie Donalda Tuska:

proponuje akcje wysyłania niepotrzebnych nam zegarków klubom PO w całym kraju. zachęcam ja wygrzebałem w piwnicy dwa budziki i na pasku z odpustu jutro wysyłam;-) z dedykacja dla novaka.

Te dwie wypowiedzi mają, podobnie jak poprzednie, ironiczny i aluzyjny charakter. Obie nawiązują do aktualnej sytuacji na polskiej scenie politycznej, czyli do spadku poparcia społecznego dla premiera i jego gabinetu ${ }^{16}$ oraz do zarzutów tygodnika „Wprost” skierowanych pod adresem ministra S. Nowaka ${ }^{17}$. Obie wyzyskują wiadomość agencyjną jedynie do zwrócenia uwagi na to, co

14 „Magda Gessler jest znaną restauratorką, artystką, malarką i pisarką, ale największą popularność zdobyła dzięki programowi «Kuchenne rewolucje»”, http://teleshow.pl/pid,173,title,MagdaGessler,gwiazda.html?ticaid=510c90 [17.06.2013].

15 Potoczne znaczenia tych słów są następujące: ,wdepnąć” "niepotrzebnie wmieszać się w coś [SPP 2006: 331], „wyrąbać się” - "przewrócić się' [SPP 2006: 354].

16 „Piątek, 19 kwietnia 2013 (12:11) Kwiecień nie był udanym miesiącem dla rządu Donalda Tuska - wynika z najnowszego badania CBOS [...] - liczba osób negatywnie oceniających działalność rządu po raz kolejny wzrosła. Teraz aż 66\% respondentów w badaniu CBOS nie jest zadowolona $\mathrm{z}$ tego jak pracuje gabinet Tuska. [...] Spada również akceptacja dla premiera. Tylko $28 \%$ ( -2 pp) jest zadowolonych, że stoi na czele rządu. 59\% (+2) ma przeciwne zdanie. [...] Biorąc jednak pod uwagę trwający prawie pięć i pół roku okres sprawowania władzy przez koalicję PO-PSL, trzeba zaznaczyć, że obecne notowania rządu i premiera Donalda Tuska są jednymi z najgorszych. Badanie przeprowadzono w dniach 4-10 kwietnia 2013 roku", http://300polityka.pl/news/2013/04/19/trwa-spadek-poparcia-dla-rzadu-donalda-tuska-oraz-jego-pomyslow-gospodarczych/ [dostęp 15.06.2013].

17 „Poniedziałek, 22 kwietnia (10:51) Minister Sławomir Nowak broni się przed zarzutami tygodnika „Wprost”. W oświadczeniu opublikowanym na stronie resortu transportu, jego szef zaprzeczył, by łączyły go niejasne związki z prywatnym biznesem. Tygodnik „Wprost” w artykule poświęconym Nowakowi [...] opisał jego kontakty między innymi ze współwłaścicielem firmy reklamowej, w ostatnich latach zdobywającej milionowe kontrakty od instytucji publicznych i państwowych firm. Tygodnik pisze też o drogich zegarkach, z którymi pokazuje się minister, a które nie figurują w jego zeznaniach majątkowych oraz o jego wizytach w bardzo drogich klubach", http://fakty.interia.pl/polska/news-minister-nowak-odpiera-zarzuty-zegarki-odda,nId,958611 [dostęp 15.06.2013]. 
dzieje się w Polsce, a co niejako przypomina trzęsienie ziemi, ale na scenie politycznej. Warto także zwrócić uwagę na jedyny element graficzny, jaki pojawił się W wypowiedzi odnoszącej się do osoby ministra S. Nowaka. Jest to emotikon;-) stanowiący swoisty komentarz do tekstu wyrażonego przez internautę słowami (czyli komentarz w komentarzu). Znak graficzny jest więc sygnałem dla innych uczestników dyskusji na forum, że ten fragment wypowiedzi ,nie jest traktowany przez nadawcę serio i nie wymaga dosłownego przyjęcia, a raczej należy go potraktować z przymrużeniem oka" [Maliszewska 2002: 152]. Przytoczone komentarze internautów w postaci pytania retorycznego i aluzyjnego oznajmienia wykraczają poza ramy głównego tematu dyskusji, są dygresjami, które odnoszą się do aktualnych wydarzeń w kraju.

Komentarzem internauty, dla którego zamieszczenie informacji o trzęsieniu ziemi stało się również jedynie pretekstem do wyrażenia swoich spostrzeżeń, jest następująca wypowiedź:

zeby tak w brukseli zaczelo i sie to wszystko rozp......lo!! mozecie krasc, klamac, oszukiac i mordowac ale za to co chcecie robic dzieciom napewno spotka was jakis kataklizm tak za kare i ku przestrodze dla tych ktorzy chca robic krzywde tym najbardziej bezbronnym ${ }^{18}$.

Jest to przykład wypowiedzi z eksplikacją semantyczną zawierającą groźbę „życzę, aby X stało się coś złego”. Taka intencja nadawcy przesądza o niezwykle emocjonalnym i dynamicznym charakterze tego komentarza, a wzmacnia ją użyte słownictwo (następujące po sobie czasowniki w formie bezokoliczników, a także wulgaryzm) oraz zwielokrotniony wykrzyknik. Postawę modalną nadawcy odzwierciedla także konstrukcja składniowa jego wypowiedzi obejmującej wypowiedzenie performatywne wyrażające życzenie, aby stało się coś złego (,żeby tak [...] zatrzęsło") oraz wypowiedzenie konstatywne, w którym pojawia się pewność, że coś złego na pewno wydarzy się w bliżej nieokreślonej przyszłości („,na pewno spotka was jakiś kataklizm tak za karę i ku przestrodze"). Jest to zatem przykład komentarza z elementami przepowiedni, w którym kataklizm trzęsienia ziemi został przywołany jako element groźby pod adresem „Brukseli”, będącej siedzibą Parlamentu Europejskiego dysponującego środkami pieniężnymi na finansowanie $m$.in. badań na ludzkich embrionach. Internauta w taki sposób wyraża swój sprzeciw i nie zgadza się z decyzjami PE.

Komentarze internautów stanowią zatem przykłady różnorodnych reakcji słownych na zaistniałe tragiczne wydarzenie. Są wśród nich zarówno wypowiedzi

18 Autor komentarza wyraźnie opowiada się za ochroną życia ludzkiego i dlatego wydaje się, że jego wypowiedź jest odniesieniem do akcji zbierania podpisów w państwach Unii Europejskiej „pod Europejską Inicjatywą Obywatelską (EIO) „Jeden z nas”. Jej celem jest zablokowanie środków unijnych na finansowanie aborcji, eksperymentów na ludzkich embrionach oraz innych działań przeciwko życiu, a także stworzenie prawodawstwa chroniącego prawo do życia dzieci od poczęcia", http://www.niedziela.pl/artykul/104619/nd/Jestes-Europejczykiem-badz-za-zyciem [dostęp 15.06.2013]. 
determinowane przez owo wydarzenie, odnoszące się bezpośrednio do niego i zawierające wyrazy współczucia dla poszkodowanych, jak i wypowiedzi, w których trzęsienie ziemi stało się punktem odniesienia do aktualnych wydarzeń w kraju i poza jego granicami.

\section{Komentarz w dyskursie medialnym}

Dyskurs medialny to zdarzenie komunikacyjne, rodzaj interakcji pomiędzy nadawcą a odbiorcą komunikatu dokonującej się przy udziale języka, to „ciąg zachowań językowych, których postać zależy od tego, kto mówi, do kogo, w jakiej sytuacji i w jakim celu" [Grabias 2003: 264]. W dyskursie medialnym ${ }^{19}$ na forum internetowym nadawca i odbiorca w momencie pojawienia się konkretnej wiadomości mają możliwość rozpoczęcia dyskusji i, posługując się słowem i znakami graficznymi (emotikonami), mogą komentować owo zdarzenie, wyrażać swoje opinie i spostrzeżenia.

Zamieszczone na forum wypowiedzi internautów, będące przedmiotem analizy, odnoszą się (bezpośrednio lub pośrednio) do podanej wiadomości o tragicznym w skutkach trzęsieniu ziemi. Wypowiedzi te są zmodyfikowanymi realizacjami wzorca komentarza jako gatunku medialnego, w którego definicjach podkreśla się ,aktualność poruszanych problemów, [...] subiektywność wywodu, interpretacyjny i perswazyjny charakter wypowiedzi, postuluje jasność i precyzję w wyrażaniu opinii [Wojtak 2004:166]. Do analizowanych komentarzy internautów można także odnieść m.in. następujące definicje tego gatunku: „wypowiedź [...] omawiająca bieżące wydarzenia [...] często z dużym subiektywizmem i zaangażowaniem emocjonalnym” [SWJP 1996: 396]; ,krótki [...] tekst ocenny, zamieszczany tuż pod tekstem informacji na jakiś ważny społecznie temat" [Fras 1999: 84], a przede wszystkim objaśnienie zawarte w ISJP „komentarz do jakiegoś wydarzenia, czyjegoś postępowania lub wyglądu, to uwaga do nich, często krytyczna lub złośliwa" [Bańko 2000: t. 1, 651]. Pojawienie się komentarza warunkują zatem, po pierwsze, obecność jakiegoś tekstu (wypowiedzi, informacji o czymś), po drugie, odniesienia do tego tekstu (czyli subiektywne i np. krytyczne, wyjaśniające skomentowanie go) [Bogdanowska 2003].

Komentarze internautów, które pojawiają się na forum jako reakcje na podaną wiadomość, to spontaniczne wypowiedzi zarówno nadawcy, jak i odbiorcy komunikatu (z przemiennością ich ról) w przestrzeni publicznej. W dyskursie medialnym $\mathrm{w}$ przestrzeni publicznej uczestnicy zdarzenia komunikacyjnego na ten fakt nie zwracają uwagi. Ich wpisy na forum mimo posługiwania się pismem

19 Przyjęta przeze mnie definicja dyskursu medialnego nawiązuje także do propozycji J. Jagodzińskiej [2002: 207-209], U. Żydek-Bednarczuk [2004b: 99-106], M. Lisowskiej-Magdziarz [2006: 16] oraz R. Szweda [2011: 19-23]. 
są bliższe językowi mówionemu, potocznemu, zawierają „,cechy oralne” [Żydek-Bednarczuk 2004b: 104]. Odzwierciedlają się one m.in. w przytoczonym poniżej fragmencie rozmowy na forum, w której wzięło udział kilka osób o wyraźnie sprecyzowanych poglądach (przeciwników i zwolenników Watykanu (papieża) oraz osoby próbującej niejako uspokoić gwałtowną wymianę zdań pomiędzy rozmówcami):

- „szkoda, ze w Watykanie trzesien ziemi nie ma!!!!”

- „to tylko kwestia czasu!!!”

- „W Watykanie nie, ale juz niedlugo potrzesie twoim domem”

- „twoim moherze potrzesie!!!”

- „Też bywają, całe Włochy leżą na terenie potencjalnie aktywnym sejsmicznie. Mają tam kilka wulkanów, oraz teren, gdzie wiele razy powstawały super-wulkany, jak te pod Yellowstone".

Pamiętając o tym, że pretekstem do tej wymiany zdań stała się wiadomość dotycząca gwałtownych wstrząsów skorupy ziemskiej w Afganistanie, można zauważyć wyzyskanie głównej informacji (trzęsienia ziemi) do rozwinięcia zgoła innego wątku na forum, niezwiązanego z podstawowym tematem. Internauci nie wyrażają np. współczucia dla ofiar, ale wyraźnie deklarują swoje poglądy, które można określić jako „za” Watykanem (w domyśle papieżem) lub „przeciwko” niemu. W kontekście tej rozmowy szczególną uwagę zwracają dwie wypowiedzi zawierające groźby, pierwsza: „,...] juz niedlugo potrzesie twoim domem” i reakcja na nią: „twoim moherze potrzesie!!!”. Odzwierciedlają się w nich odmienne poglądy internautów, czyli przeciwnika i zwolennika papieża. Charakterystyczne, że w tej wymianie zdań pojawia się pejoratywne określenie „moherze” ${ }^{20}$ skierowane do interlokutora, które deprecjonuje i jednocześnie identyfikuje poglądy odbiorcy tej wypowiedzi. O tym, że rozmówcy są zdenerwowani, świadczą zwielokrotnione wykrzykniki znajdujące się na końcu poszczególnych replik. Gdyby rozmawiali w pozawirtualnej rzeczywistości, można by na pewno usłyszeć podniesiony ton ich głosu w wypowiadanych przez nich groźbach. Wykrzykniki oddają gwałtowne emocje towarzyszące wypowiadanym słowom i wzmacniają zawarte w przekazach nadawcy i odbiorcy intencje. „Oralność” przytoczonych wypowiedzi uzewnętrznia się więc w samym zapisie poszczególnych replik, ale także m.in. w skrótowości wypowiedzeń, ich niepełnej, eliptycznej strukturze.

W kontekście analizowanego fragmentu dyskusji na forum zwraca jednak uwagę głos odmienny od przytoczonych wyżej wypowiedzi. Ta odmienność wynika z przyjętej przez nadawcę strategii wypowiedzi ${ }^{21}$, czyli chęci uspokojenia

${ }^{20}$ W kontekście tej wypowiedzi „moher” jest skrótem wyrażenia „moherowe berety”, jakie zaczęło funkcjonować w języku polityków na określenie zwolenników „Radia Maryja”, http://sjp.pl/ moher [dostęp 18.06.2013].

${ }_{21}$ Taki rodzaj strategii można określić jako behawioralną, polegającą na „sterowaniu zachowaniem interlokutorów [...] za pomocą działania werbalnego". Nadawca chce zablokować werbal- 
wzburzonych i zdenerwowanych rozmówców oraz zwrócenia ich uwagi na meritum dyskusji (zjawisko trzęsienia ziemi). Stąd w jego wypowiedzi pojawiają się konkretne, rzeczowe informacje: ,[...] całe Włochy leżą na terenie potencjalnie aktywnym sejsmicznie. Mają tam kilka wulkanów, oraz teren, gdzie wiele razy powstawały super-wulkany, jak te pod Yellowstone". Ta replika to niemalże krótki wykład z zakresu sejsmologii i geografii, celowo zamieszczony, aby wskazać rzeczywiste przyczyny wywołujące kataklizm i spowodować, że pozostali rozmówcy zmienią ton swojej rozmowy. Elementem tej wypowiedzi, na który należy zwrócić uwagę, jest ukształtowanie składniowe, nietypowe dla szybkiej wymiany zdań w Internecie. Analizowana wypowiedź zawiera dwa wyraźnie wydzielone zdania złożone, zbudowane poprawnie stylistycznie z zachowaniem zasad interpunkcyjnych (duża litera na początku zdania, kropka na końcu). Staranny zapis, zachowanie cech oficjalności, rzeczowy ton tej repliki jako reakcji na wcześniejsze głosy w dyskusji, wyróżniają ten wpis spośród innych. Nie można jednak tej wypowiedzi uznać za reprezentatywną dla dyskursu medialnego.

Forum dyskusyjne to przestrzeń, w której dyskurs medialny, rozumiany jako zdarzenie komunikacyjne, rodzaj interakcji pomiędzy nadawcą i odbiorcą, nosi przede wszystkim cechy dyskursu nieoficjalnego, który wyróżnia „minimalizm formalno-językowy" [Ogonowska, Skowronek 2005: 300]. Repliki poszczególnych rozmówców charakteryzują uproszczenia składniowe, krótkie (niekiedy jednowyrazowe), niedokończone, eliptyczne, luźno powiązane ze sobą, wypowiedzenia, stosowanie kolokwialnego słownictwa, w tym wulgaryzmów. Są to tworzone spontanicznie potoki składniowe, w których brak związków przyczynowo-skutkowych. Poszczególne wypowiedzi na forum można więc określić jako „rozmowy pisane” [Kaczmarek 2002: 134], stanowiące połączenie elementów typowych dla kodów mówionego i pisanego [Ogonowska, Skowronek 2005: 301; Dąbrowska 2000: 95-111].

Analiza komentarzy internautów pozwoliła zwrócić uwagę na sposób odniesienia się internautów do wiadomości o tym, co wydarzyło się poza granicami Polski. Wyrażone w słowach reakcje poszczególnych rozmówców na forum były różnorodne, ale można je podzielić na dwa wyraźnie przeciwstawne kręgi. W pierwszym, obejmującym nieliczne wypowiedzi, mieszczą się wpisy bezpośrednio związane z komentowanym wydarzeniem, zawierające wyrażone wprost lub pośrednio wyrazy współczucia dla poszkodowanych. Natomiast obszerny drugi krąg stanowią takie wypowiedzi, w których trzęsienie ziemi stało się jedynie okazją do wyrażenia nieprzychylnych opinii na temat znanych postaci ze świata polityki czy mediów. Słowo w komentarzach internautów informuje więc o sposobie postrzegania i interpretacji rzeczywistości przez nadawcę i odbiorcę komunikatu, o ich emocjach i poglądach. Dyskurs medialny jako aktywne działanie

ną degradację partnera [Habrajska 2002: 166, 169] i przerwać ten wątek dyskusji poprzez wypowiedź o neutralnym, rzeczowym charakterze. 
komunikacyjne internautów charakteryzuje przede wszystkim nieoficjalność, zbliżenie do języka mówionego, języka rozmowy. Sprzyja temu szybkość wymiany zdań pomiędzy rozmówcami na forum, która powoduje, że najważniejsze staje się samo przekazywanie opinii i komentowanie danego wydarzenia, natomiast mniej ważne (a niekiedy w ogóle nieważne) są kwestie poprawności składniowej czy stylistycznej.

\section{Bibliografia}

Bogdanowska M. [2003], Komentarz i komentowanie. Zagadnienia konstrukcji tekstu, Wydawnictwo Uniwersytetu Śląskiego, Katowice.

Dąbrowska M. [2000], Język e-maila jako hybryda mowy i pisma, [w:] G. Szpila (red.), Język trzeciego tysiąclecia, Wydawnictwo „Tertium”, Kraków.

Habrajska G. [2002], Strategie konwersacyjne w internetowych grupach dyskusyjnych, [w:] G. Szpila (red.), Język trzeciego tysiąclecia II, t. I: Nowe oblicza komunikacji we wspótczesnej polszczyźnie, Wydawnictwo „Tertium”, Kraków.

Fras J. [1999], Dziennikarski warsztat językowy, Wydawnictwo Uniwersytetu Wrocławskiego, Wrocław.

Golus B. [2004], Fenomen rozmów internetowych i ich języka, [w:] M. Kita (red.), Dialog a nowe media, Wydawnictwo Uniwersytetu Śląskiego, Katowice.

Grabias S. [2003], Języ w zachowaniach społecznych, Wydawnictwo UMCS, Lublin.

Grzenia J. [2007], Komunikacja językowa w Internecie, Wydawnictwo Naukowe PWN, Warszawa.

Inny stownik języka polskiego [ISJP] [2000], M. Bańko (red.), t. 1, Wydawnictwo Naukowe PWN, Warszawa.

Jadacka H., Markowski A., Zdunkiewicz-Jedynak D. [2008], Poprawna polszczyzna. Hasła problemowe, Wydawnictwo Naukowe PWN, Warszawa.

Kaczmarek M. [2002], Specyfika językowa i graficzna krótkich wiadomości tekstowych (SMS-ów), [w:] K. Michalewski (red.), Tekst w mediach, Wydawnictwo Uniwersytetu Łódzkiego, Łódź.

Lisowska-Magdziarz M. [2006], Analiza tekstu w dyskursie medialnym. Przewodnik dla studentów, Wydawnictwo UJ, Kraków.

Maliszewska A. [2002], Wirtualna buźka. Modyfikująca rola znaków graficznych w komunikacji internetowej, [w:] K. Michalewski (red.), Tekst w mediach, Wydawnictwo Uniwersytetu Łódzkiego, Łódź.

Marcjanik M. [1997], Polska grzeczność językowa, Wydawnictwo Wyższej Szkoły Pedagogicznej im. J. Kochanowskiego, Kielce.

Ogonowska A., Skowronek B. [2005], „Język na nielegalu”, czyli wpływ multimediów na komunikację werbalna młodego pokolenia. O nowa metodologię badań, [w:] A. Dytman-Stasieńko, J. Stasieńko (red.), Język@ multimedia, Wydawnictwo Naukowe Dolnośląskiej Szkoły Wyższej Edukacji TWP, Wrocław.

Pachowicz M. [2011], Nagłówek wiadomości zamieszczonej w portalu internetowym $w$ kontekśsie celów komunikacyjnych, [w:] I. Matusiak-Kempa, S. Przybyszewski (red.), Nowe zjawiska w języku, tekście, komunikacji III. Kontekst a komunikacja, Centrum Badań Europy Wschodniej UWM, Olsztyn.

Stownik polszczyzny potocznej [SPP] [2006], Czeszewski M., Wydawnictwo Naukowe PWN, Warszawa.

Słownik wspótczesnego języka polskiego [SWJP] [1996], B. Dunaj (red.), Wydawnictwo Wilga, Warszawa. 
Szwed R. [2011], Nieswoistość analizy dyskursu w nance o komunikacji. Dyskurs jako przedmiot i metoda badań, [w:] Zawartość mediów, czyli rozważania nad metodologia badań medioznawczych, T. Gackowski (red.), Wydawnictwo ASPRA-JR, Warszawa.

Wierzbicka A. [1983], Genry mowy, [w:] T. Dobrzyńska, E. Janus (red.), Tekst i zdanie. Zbiór studiów, Zakład Narodowy im. Ossolińskich Wydawnictwo PAU, Wrocław-Warszawa-KrakówGdańsk-Lódź.

Wojtak M. [2004], Gatunki prasowe, Wydawnictwo Uniwersytetu Marii Curie-Skłodowskiej, Lublin.

Żydek-Bednarczuk U. [2004a], Tekst w Internecie i jego wyznaczniki, [w:] M. Kita (red.), Dialog a nowe media, Wydawnictwo Uniwersytetu Śląskiego, Katowice.

Żydek-Bednarczuk U. [2004b], Zmiany w zachowaniach komunikacyjnych a nowe odmiany językowe (odmiana medialna), [w:] K. Michalewski (red.), Współczesne odmiany języka narodowego, Wydawnictwo Uniwersytetu Łódzkiego, Łódź.

\section{Netografia}

http://fakty.interia.pl/polska/news-minister-nowak-odpiera-zarzuty-zegarki-odda,nId,958611 [dostęp 15.06.2013]

http://fakty.interia.pl/swiat/news-siedem-osob-zginelo-w-trzesieniu-ziemi-dziesiatki-rannych,nId,959560\#commentsZone List [dostęp 24.04.2013].

http://forum.interia.pl/siedem-osob-zginelo-w-trzesieniu-ziemi-dziesiatki-rannych-komentarze,catId,1895,dId,2195066 [dostęp 24.04.2013].

http://sjp.pl/moher [dostęp18.06.2013].

http://teleshow.pl/pid,173,title,Magda-Gessler,gwiazda.html?ticaid=510c90 [dostęp 17.06.2013].

http://300polityka.pl/news/2013/04/19/trwa-spadek-poparcia-dla-rzadu-donalda-tuska-oraz-jego-pomyslow-gospodarczych/ [dostęp 15.06.2013].

http://zyciegwiazd.onet.p1/302409,0, marta-grycan-z-corkami-wiktoria-i-weronika-czy-to-,fotonews_detail.html [dostęp 15.06.2013].

http://www.interia.pl/ [dostęp 24.04.2013].

http://www.niedziela.pl/artykul/104619/nd/Jestes-Europejczykiem-badz-za-zyciem [dostęp 15.06.2013]. 